Jurnal Kompetitif : Media Informasi Ekonomi Pembangunan, Manajemen dan Akuntansi

Vol. 6 No. 2 September 2020

\title{
AKUNTABILITAS PENGELOLAAN DANA DESA DALAM UPAYA PEMBANGUNAN DI DESA SAJANG KECAMATAN SEMBALUN
}

\author{
Baiq Hanita Septiani Audia ${ }^{1}$ \\ Hj. Indah Ariffianti ${ }^{2}$ \\ Baiq Desthania Prathama ${ }^{3}$ \\ Sekolah Tinggi Ilmu Ekonomi AMM Mataram \\ hanitaaudia@gmail.com \\ indahariffianti99@gmail.com \\ desthania.27@gmail.com
}

\begin{abstract}
ABTRACT
This study aims to determine the Accountability of village fund Management to improve development in Sajang Village, Sembalun District, which consists of five stages, namely Planning, Implementation, administration, reporting and accaountability. This type of research is a case study using a descriptive analysis approach. In this study, the techniques of data collection use are interviews, questionnaires and documentatation. The data analysis technique use in this study is a quanlitative descriptive analysis technique.The results of this study indicate that the planning, implementation, reporting, administration and accountability system of accountability has applied the principle of accountability. Thia is evidenced from the results of interviews with documentation and questionnaires.
\end{abstract}

Keywords : accountability, Managemen Village Fund

\section{PENDAHULUAN}

Pemerintahan desa merupakan lingkup terkecil dalam suatu pemerintahan Republik Indonesia.Meskipun demikian, Pemerintahan desa memiliki peranan yang cukup besar dalam pembangunan. Jika pembangunan di setiap desa dapat berjalan secara maksimal, maka tujuan dari pemerintah pusat untuk membuat pemerataan kesejahteraan dan pembangunan yang adil akan dapat terwujud. Namun, kondisi beberapa daerah di Indonesia belum sesuai dengan harapan pemerintah pusat.Oleh karena itu, peran dari pemerintah daerah cukup vital dalam otonomi daerah dikarenakan desa memiliki hak kebebasan untuk membuat regulasi dan aturan dalam kehidupan desa sebelum diatur oleh pemerintah daerah.Peran dari pemerintah daerah diharapkan dapat membimbing serta mengawasi setiap kebijakan maupun program 
Jurnal Kompetitif : Media Informasi Ekonomi Pembangunan, Manajemen dan Akuntansi Vol. 6 No. 2 September 2020

Dengan adanya Dana Desa menjadikan sumber pemasukan di setiap desa akan meningkat. Meningkatnya pendapatan desa yang diberikan oleh pemerintah untuk meningkatkan taraf hidup masyarakat desa.Tetapi dengan adanya Dana Desa juga memunculkan permasalahan yang baru dalam pengelolaan, pemerintah desa diharapkan dapat mengelola sesuai dengan peraturan perundang-undangan secara efisien, ekonomis, efektif serta transparan dan bertanggung jawab dengan memperhatikan rasa keadilan dan kepatuhan serta mengutamakan kepentingan masyarakat.

Pada prinsipnya dana desa bertujuan untuk meningkatkan kesejahteraan masyarakat, menggerakan perekonomian dan membangun kesejahteraan masyarakat, menggerakan perekonomian dan membangun kemandirian desa. Dengan demikian alokasi dana desa diharapkan bisa meningkatkan pembangunan. Begitupun dengan pengelolaan keuangan desa yang diberikan kepada daerah melalui Dana Desa pada prinsipnya tetap mengacu pada pokok pengelolaan keuangan daerah.

Penelitian ini akan membahas mengenai Akuntabilitas Pengelolaan Dana Desa Dalam Upaya Meningkatkan Pembangunan Di Desa Oleh Pemerintah Desa. penelitian ini bersifat studi kasus dengan mengambil objek penelitian di Desa Sajang yang merupakan salah satu Desa yang terletak di Kecamatan Sembalun Lawang . Ada beberapa potensi yang dimiliki Desa Sajang dari potensi pertanian, perkebunan, peternakan hingga potensi wisata. Pertanian di Desa Sajang itu adalah holti kultura yang mempunyai nilai ekonomis tinggi seperti bawang putih, bawang merah, cabai, tomat ,kubis dan lain-lain yang mana hasilnya jarang bisa ditanam di tempattempat lain.

Dalam dana Desa di Desa Sajang masih terbatas artinya dengan dana yang ada dengan kompleksitas kekurangan masyarakat seperti infrastruktur jalan, infrastruktur dasar, penyaluran air bersih, pemasangan pipa dan lain sebagainya dengan dana masih belum menyukupi. Terkain dengan kendala pembangunan di Desa Sajang degan adanya program pemerintah sifat swadaya gotong royong masyarakat sudah mulai berkurang karena sudah adanya para pekerja luar yang sudah di bayar oleh pemerintah sehingga masyarakat kurang perduli terhadap pembangunan dan pemeliharaan pekerjaan. Namun bagaimanapun dengan adanya Dana Desa yang di transfer ini memberikan energy baru untuk melakukan inovasi terhadap beberapa kegiatan atau programprogram yang bisa mendapatkan pendapatan desa walaupun sampai saat ini belum maksimal. 
Jurnal Kompetitif : Media Informasi Ekonomi Pembangunan, Manajemen dan Akuntansi

Vol. 6 No. 2 September 2020

Table 1.1

Anggaran Dana Desa 2017-2019

\begin{tabular}{|c|c|c|c|c|}
\hline NO & Keterangan & $\mathbf{2 0 1 7}(\mathbf{R p})$ & $\mathbf{2 0 1 8}(\mathbf{R p})$ & $\mathbf{2 0 1 9}(\mathbf{R p})$ \\
\hline $\mathbf{1}$ & Dana Desa & 875.600 .000 & 1.110 .358 .000 & 1.392 .489 .000 \\
\hline
\end{tabular}

Sumber APBN 2017-2019

\section{TINJAUAN PUSTAKA}

\section{Dana Desa}

Menurut Peraturan Pemerintah Republik Indonesia nomor 06 tahun 2014 tentang Dana Desa yang bersumber dari anggaran pendapatan dan belanja desa "Dana Desa adalah dana yang bersumber dari anggaran pendapatan dan belanja Negara yang diperuntukan bagi Desa yang ditransfer melalui anggaran pendapatan dan belanja daerah kabupaten/kota dan digunakan untuk membiayai penyelenggaraan pemerintah, pelaksanaan pembangunan, pembinaan masyarakat, dan pemberdayaan masyarakat". 1

Dana desa dalam APBN ditentukan 10\% dari dan di luar dana transfer daerah secara bertahap. Dana desa yang diterima setiap desa dihitung dan dialokasikan berdasarkan jumlah penduduk, angka kemiskinan, luas wilayah, dan tingkat kesulitan geografis.

\section{Pengertian Akuntabilitas}

Menurut peraturan perundang-undangan No. 6 Tahun 2014 tentang desa, menjelaskan bahwa akuntabilitas adalah asas yang menentukan bahwa setiap kegiatan dan hasil ahir kegiatan penyelenggaraan pemerintah desa harus dipertanggungjawabkan kepada masyarakat desa sesuai dengan ketentuan perundang-undangan.

Menurut Mardiasmo (2014:44) menerangkan bahwa akuntabilitas adalah kewajiban pihak pemegang amanah (agent) untuk memberikan pertanggungjawaban, menyajikan, mrlaporkan dan mengungkapkan segala aktifitas dan kegiatan yang menjadi tanggung jawabnya kepada pihak 
Jurnal Kompetitif : Media Informasi Ekonomi Pembangunan, Manajemen dan Akuntansi Vol. 6 No. 2 September 2020

pemberi amanah (principal) yang memiliki hak dan kewenangan untuk meminta pertanggungjawaban tersebut. $^{2}$

\section{3. pengelolaan keuangan Desa}

berdasarkan Permendagri Nomor 113 tahun 2014 tentang pengelolaan keuangan desa dalam peraturan Menteri yang dimaksud dengan , Pengelolaan Keuangan Desa adalah keseluruhan kegiatan yang meliputi perencanaan, pelaksanaan, penatausahaan, pelaporan, dan pertanggungjawaban keuangan Desa.

1. Perencanaan

berdasarkan Permendagri Nomor 113 tahun 2014 pasal 20 ayat (1) dan ayat (2) tentang perencanaan menyatakan :

(1) Sekretaris desa menyusun Rancangan Peraturan Desa tentang APBDesa berdasarkan RKPDesa tahun berkenan.

(2) Sekretaris Desa menyampaikan rancangan Peraturan Desa tentang APBDesa kepada Kepala Desa.

2. Pelaksanaan

berdasarkan Permendagri Nomor 113 tahun 2014 pasal 24 ayat (1) tentang pelaksanaan menyatakan :

(1) Semua penerimaan dan pengeluaran desa dalam rangka pelaksanaan kewenangan desa dilaksanakan melaui rekening kas desa.

3. Penatausahaan

berdasarkan Permendagri Nomor 113 tahun 2014 pasal 20 ayat 1 (satu) dan ayat 2 (dua) tentang penatausahaan menyatakan

(1) Penatausahaan dilakukan oleh Bendahara Desa.

(2) Bendahra Desa wajib melakukan pencatatan setiap penerimaan dan pengeluaran serta melakukan tutup buku setiap ahir bulan secara tertib.

\footnotetext{
2 Mardiasmo. 2004. Akuntansi Sektor Publik. Yogyakarta: Andi Offset.
} 
Jurnal Kompetitif : Media Informasi Ekonomi Pembangunan, Manajemen dan Akuntansi

Vol. 6 No. 2 September 2020

berdasarkan Permendagri Nomor 113 tahun 2014 pasal 36 penatausahaan penerimaan dan pengeluaran sebagaimana dimaksud dalam pasal 35 ayat (2), menggunakan
a. Buku kas umum
b. Buku kas pembantu pajak: dan
c. Buku Bank

4. Pelaporan

berdasarkan Permendagri Nomor 113 tahun 2014 pasal 37 ayat (1) tentang pelaporan menyatakan :

(1) Kepala desa menyampaikan laporan realisasi pelaksanaan APBDesa kepada Bupati/Walikota berupa:

a. Laporan semester pertama; dan

b. Laporan semester ahir tahun.

5. Pertanggungjawaban

berdasarkan Permendagri Nomor 113 tahun 2014 pasal 38 ayat (1) tentang pertanggungjawaban menyatakan:

(1) Kepala desa menyampaikan laporan pertanggungjawaban realisasi pelaksanaan APBDesa kepada Bupati/Walikota setiap ahir tahun anggaran.

\section{Pembangunan}

Menurut kamus besar bahasa Indonesia pembangunan adalah proses, perbuatan, cara membangun segala bidang.

Menurut Siagian dalam M. Farid Ma'ruf pembangunan merupakan rangkaian usaha yang secara sadar dilakukan. Artinya, keadaan yang lebih baik, yang didambakan oleh suatu masyarakat, serta pertumbuhan yang diharapkan yang akan terus berlangsung, tidak terjadi dengan sendirinya, apalagi secara kebetulan.

\section{A. Pembangunan Desa}

Pembangunan desa menurut Permendagri Nomor 114 tahun 2014 pasal 1 (satu) ayat 9 (sembilan) tentang pedomen pembangunan desa, "pembangunan desa adalah upaya peningkatan kualitas hidup dan kehidupan untuk sebesar-besarnya untuk kesejahteraan ,masyarakat Desa”. 
Jurnal Kompetitif : Media Informasi Ekonomi Pembangunan, Manajemen dan Akuntansi Vol. 6 No. 2 September 2020

Sedangkan menurut (Sutoro, 2015) pembangunan desa merupakan ssuatu upaya yang dilakukan demi meningkatkan kualitas hidup dan kehidupan masyarakat di suatu daerah dimana pembangunan desa dilakukan oleh seluruh lapisan baik pemerintah maupun masyarakat.

\section{III.METODE PENELITIAN}

\section{Jenis Penelitian}

Penelitian ini merupakan jenis penelitiandengan menggunakan teknik studi kasus pendekatan analisis deskriptif.MenurutWiyono (2011: 135), "Teknis studi kasus adalah salah satu teknik pengumpulan data yang dibutuhkan dengan cara menarik sampel dari unit sampel tertentu yang berhubungan dan dipelajari secara lebih mendalam".Menurut Sujarweni(2014:65),"Sampeladalahbagiandarisejumlahkarakteristik yang dimiliki oleh populasi yang digunkan untuk penelitian. Populasi adalah keseluruhan jumlah yang terdiri atas objek dan subjek yang mempunyai karakteristik dan kualitas tertentu yang ditetapkan oleh peneliti untuk diteliti dan kemudian ditarikkesimpulannya.

\section{Teknik Pengumpulan Data}

Teknik pengumpulan data yang digunakan dalam penelitian ini adalah kuesioner wawancara dan dokumentasi.

\section{a. Kuesioner}

menurut Sugiyono (2017:14), kuesioner merupakan teknik pengumpulan data yang dilakukan dengan cara memberikan seperangkat pertanyaan tertulis kepada responden untuk dijawabnya. Kuesioner disebar kepada responden yang berjumlah 10 orang. Kuesioner berisi daftar pertanyaan mengenai akuntabilitas pengelolaan dana desa, dimana pertanyaan tersebut dimulai dari tahap perencanaan, pelaksanaan, penatausahaan, pelaporan hingga tahap pertanggungjawaban.

\section{b. Wawancara}

Wawancara adalah pertemuan dua orang bertukar informasi dan ide melalui Tanya jawab, sehingga dapat dikontruksikan makna dalam suatu topic tertentu. (sugiyono, 2014) Menurut Maryaeni (2005;70), wawancara merupakan salah satu pengambilan data yang dilakukan melalui kegiatan komunikasi lisan dalam bentuk terstruktur, semi terstruktur, dan tak terstruktur.

1) WawancaraTerstruktur

Dalam wawancara terstruktur pewawancara menyampaikan beberapa pertanyaan yang sudah disiapkan pewawancara sebelumnya (Esther Kuntjara, 2006;68), jadi wawancara 
Jurnal Kompetitif : Media Informasi Ekonomi Pembangunan, Manajemen dan Akuntansi

Vol. 6 No. 2 September 2020

terstruktur adalah wawancara yang dilakukan dengan terlebih dahulu membuat pertanyaan dan kemudian menyusun pertanyaan dalam bentuk daftar-daftar pertanyaan yang akan diajukan kepada informan.

\section{Dokumentasi}

Teknik dokumentasi adalah catatan peristiwa yang sudah berlalu.Dokumen bisa berbentuk tulisan, atau karya-karya monumental seseorang (sugiyono, 2012). Dokumentasi yang digunakan pada penelitian ini berupa dokumen-dokumen terkait tentang pengelolaan dana desa

4. jenis dan Sumber Data

\section{A. Jenis Data}

Berdasarkan jenis penelitian ini menggunakan data kualitatif dan kuantitatif. Data kualitatif adalah data yang tidak dapat diukur dan dihitung tetapi tidak dapat memberikan informasi tambahan pagi peneliti. Data kuantitatif adalah data yang berupa angka yang dapat dihitung secara nyata. Jenis data kualitatif pada penelitian ini yakni berupa jawaban yang diperoleh dari hasil kuesioner dan wawancara oleh peneliti pada responden, sedangkan jenis data kuantitatif pada penelitian ini yakni berupa dokumen-dokumen yang terkait pengelolaan dana desa pada desa Sajang.

B. Sumber Data

1. Data Primer

Data primer adalah data yang diperoleh langsung dari tangan pertama oleh peneliti, sumber data primer berasal dari individu, diskusi focus group, panel respoden yang berbentuk khusus oleh peneliti dan dari mana opini isu khusus diperoleh. (Imam, 2016;93)

\section{Data Sekunder}

Data sekunder adalah informasi yang dikumpulkan oleh orang lain bukan oleh peneliti dalam melaksanakan penelitian. Ada beberapa sumber data sekunder yaitu, buku, dan jurnal, publikasi pemerintah tentang indicator ekonomi, data sensus, abstrak statistic, media, laporan tahunan perusahaan.(Imam, 2016; 94).

\section{HASIL DAN PEMBAHASAN}

A. Akuntabilitas pengelolaan Dana Desa upaya meningkatkan pembangunan dalam proses perencanaan, pelaksanaan, penatausahaan, pelaporan dan pertanggungjawaban. 
Jurnal Kompetitif : Media Informasi Ekonomi Pembangunan, Manajemen dan Akuntansi

Vol. 6 No. 2 September 2020

Dalam esensinya pembangunan sangan penting untuk menunjang kegiatan yang ada di desa baik membantu meningkatkan tarap hidup masyarakat desa. Setelah peneliti mekakukan teknik kuesioner dan wawancara tentang pembangunan di Desa Sajang maka peneliti bisa tarik beberapa kesimpulan yaitu penggunaan Dana Desa untuk pembangunan di 7 dusun Desa Sajanag sudah berjalan dengan semestinya sesuai dengan anggaran yang telah ditetapkan oleh pemerintah desa, hal ini bisa dilihat dari akses jalan yang sesudah memadai baik pembuatan jalan baru maupun perbaikan jalan masing-masing dusun, pembuatan gedung serbaguna yang bisa digunakan untuk banyak hal yang bermanfaat bagi masyarakat desa Sajang dan lain-lain.

\section{Akuntabilitas perencanaan pengelolaan Dana Desa upaya dalam pembangunan}

Dari data di atas yang di dapat metode wawancara, kuesioner dan dokumentasi dapat di jelaskan bahwa pada tahap perencanaan dana desa sudah di lakukan seuai perinsip akuntabilitas dalam partisipasi masyarakat, terbukti sebelum di laksanakan kegiatan terlebih dahulu dilakukan musyawarah desa atau musrembang guna melaksanakan perencanaan pembagunan. Penerapan sistem akuntabilitas pengelolaan dana desa bedasarkan data dan informasi pada waktu penelitian di desa Sajang, keuangan desa di kelola berdasarkan asas-asas akuntabel (dapat di pertanggung jawabkan).

\section{Akuntabilitas pelaksanaan pengelolaan Dana Desa upaya dalam pembangunan}

Pada tahap pelaksanaan kegiatan-kegiatan atau program-program yang bersumber dari dana desa menunjukan bahwa telah sesuai dengan aturan yang sudah berlaku. Yang berarti bahwa dalam pelaksaan dana desa sudah melaksanakan perinsip akuntabilitas karena untuk menyampaikan informasi kepada masyarakat, pemerintah desa membuat papan informasi sebagai bentuk sosialisasi agar masyarakat bisa mengetahi tentang program Dana Desa.

\section{Akuntabilitas penatausahaan pengelolaan Dana Desa upaya dalam pembngunan}

Pada tahap penatausahaan yang dilakukan oleh bendahara desa dimana bendahara desa telah melakukan pencatatan untuk penerimaan dan pengeluaran serta melakukan tutup buku di akhir bulan dan telah mempertanggungjawabkan uang sesuai laporan pertanggung jawaban. Penatausahaan pengelolaan keungan desa sudah dilaksanakan dengan baik, terlihat dengan proses pencatatan dan pertanggungjawak yang teratur dari bendahara desa pada setiap akhir periodenya sehingga dapat di simpulkan bahwa telah tercapai akuntabilitas dalam penatausahaan dalam bendahara..

\section{Akuntabilitas Pelaporan pengelolaan Dana Desa upaya dalam pembangunan}


Jurnal Kompetitif : Media Informasi Ekonomi Pembangunan, Manajemen dan Akuntansi Vol. 6 No. 2 September 2020

Laporan merupakan salah satu bentuk pertanggungjawaban dan pengungkapan informasi laporan keungan dari pelaksaan kepada Kepala Desa maupun kepada masyarakat.Kepala Desa menyampaikan laporan realisasi pelaksanaan APBDes kepada Bupati / Wali Kota setiap akhirbulan tahun anggaran.Pelporan bulanan dan laporan masing-masing tahapan kegiatan, salah satunya adalah bidang pembangunan dan pemeliharan jalan. Dalam pelaksanaan program Dana Desa bahwa pada tahap pelaporan telah dibuktikan dengan pertanggungjawaban program Dana Desa dan APBBDes kepada perintah tingkat atasnya dilakukan secara periodik. Semua pengeluaran dan penggunaan dari Dana Desa di bukukan sedemikian rupa oleh bendahara di Desa Sajang sesuai dengan petunjuk yang ada sehingga mendapatkan hasil yang sesuai dengan yang ada di perencanaan yaitu bisa di katagorikan perinsip akuntabilitas pada pelaporan sudah di jalankan atau dilaporkan dengan baik dan $100 \%$ telah sesuai.

\section{Akuntabilitas pertanggungjawaban pengelolaan Dana Desa upaya dalam pembangunan}

Dari sisi akuntabilitas, pelaksanaan dana desa di Desa Sajang telah memenuhi teori akuntabilitas. Hal ini di dukung penerapan di lapangan yang menunjukan bahwa pertanggungjawaban secara fisik sudah cukup baik.Dari data di atas melalui metode wawancara, kuesioner dan dokumentasi menunjukan bahwa pertanggung jawaban APBDes di Desa Sajang dalam satu tahun anggaran sudah sangat baik dan akuntabilitasnya sudah baik di lihat dari segi fisik maupun secara administrasi.

\section{SIMPULAN DAN SARAN}

\section{Kesimpulan}

Berdasarkan hasil pembahasan Akuntabilitas Pengelolaan Dana Desa Dalam Upaya Meningkatkan Pembangunan Di Desa Sajang Kecamatan Sembalun, dapat di ambil beberapa kesimpulan sebagai berikut:

1. Akuntabilitas Perencanaan Dana Desa Di Desa Sajang telah di laksanakan dengan baik. Hal ini buktikan oleh hasil wawancara dan kuesioner dengan Kepala Desa dan Staf Desa yang bersangkutan, bahwa secara bertahap konsep pembangunan parsipatif masyarakat Desa yang dibuktikan dengan penerapan prinsip partisipasi dan akuntabilitas guna pembelajaran masyarakat Desa dalam rangka mewujudkan pemberdayaan masyarakat desa melalui forum musrembangDes. 
Jurnal Kompetitif : Media Informasi Ekonomi Pembangunan, Manajemen dan Akuntansi Vol. 6 No. 2 September 2020

2. Akuntabilitas pelaksanaan dana Desa di Desa Sajang telah menerapkan prinsip partisipatif akuntabilitas. Hal ini di buktikan oleh hasil wawancara dan kuesioner dengan Kepala Desa dan Staf Desa yang bersangkutan bahwa penerapan prinsip akuntabilitas terpenuhi dengan adanya informasi tentang kegiatan-kegiatan tau program-program yang bersumber dari Dana Desa. Pada tahap pelaksanaan menunjukkan bahwa pelaksanaan Dana Desa sudah melakukan prinsip akuntabilitas. Penerapan prinsip akuntabilitas pada tahap pelaksaan ini masih sebatas pada petanggungjawaban fisik. Sedangkan untuk asminitrasi sudah dilakukan dengan baik dan sesuai namun tetap dalam pengawasan dan pembinaan agar sesuai dengan peraturan perundang-undangan.

3. Akuntabilitas penatausahaan Dana Desa Di Desa Sajang di laksanakan dengan baik. Hal ini dibuktikan oleh hasil wawancara dan kuesioner dengan Kepala Desa dan Staf Desa yang bersangkutan. Pada tahap penatausahaan keuangan Desa di Desa Sajang telah sesuai dengan prosedur yang dilakukan oleh bendahara Desa dan prosedur penatausahaan yang telah diatur dalam permendagri No 13 Tahun 2014 hingga tercata dengan baik dan teperinci yang dituangkan dalam tiap laporan penyerapan Dana Desa dan laporan realisasi APBDes.

4. Akuntabilitas Pelaporan Dana Desa Di Desa Sajang telah menerapkan prinsip akuntabulitas. Hal ini dibuktikan dari hasil wawancara dan kuesioner dengan Kepala Desa dan Straf Desa yang bersangkutan, dalam penyampaian laporan realisasi pelaksanaan APBDes tidak pernah mengalami keterlambatan. Di karenakan TPK (Tim Pengelola Kegiatan) telah menerapkan prinsip akuntabilitas dilakukan dengan laporan masing-masing tahapan kegiatan yang mengacu pada peraturan yang ada. Prinsip penerimaan dan pengeluaran di lakukan dengan melengkapi dokumen dan bukti lainnya yang lengkap dan sah.

5. Akuntabilitas Pertanggung Jawaban Dana Desa Di Desa Sajang telah menerapkan prinsip akuntabilitas. Hal ini dibuktikan dengan hasil wawancara dan kuesioner dengan Kepala Desa dan Staf yang bersangkutan bahwa prinsip akuntabilitas di laksanakan dengan bentuk pertanggung jawaban pengelolaan Dana Desa pada masyarakat yakni denga bentuk pisik sedangkan kepada pemerintah diatasnya dengan mengunakan format laporan pertanggung jawaban realisasi pelaksanaan APBDes sesuai denga peraturan pemerintah. Perinsip akuntabilitas di buktikan secara teknik sudah cukup baik.

\section{Saran}


Jurnal Kompetitif : Media Informasi Ekonomi Pembangunan, Manajemen dan Akuntansi Vol. 6 No. 2 September 2020

Berdasrkan kesimpulan dari hasil penelitian diatas, ada beberapa saran dapat diajukan penulis terhadap beberapa pihak yang terkait dengan skripsi ini sebagai berikut:

1. Bagi pihak perangkat Desa yang ada di Desa Sajang penelitian ini diharapkan dapat dijadikan sebagai masukan dalam meningkatkan peran perangkat Desa dalam melakukan akuntabilitas pengelolaan Dana Desa. Perangkat Desa harus lebih meningkatkan pengetahuannya dalam hal pengelolaan Dana Desa khususnya mengenai perencanaan, Pelaksanaan, Penatausahaan, Pelaporan dan pertanggugjawaban tentang Dana Desa.

2. Penelitian ini hanya membahas pengelolaan teknis keuangan desa yaitu mengenai perencanaan, pelaksanaan, penatausahaan, pelaporan dan pertanggungjawaban. sehingga saran bagi peneliti selanjutnya agar membahas komponen pengelolaan keuangan desa secara detai dan mendalam termasuk tahapan pembinaan dan pengawasannya.

\section{DAFTAR PUSTAKA}

Thomas. 2013. Pengelolaan Dana Desa Dalam Upaya Meningkatkan Pembangunan di Desa Sebawang Kecamatan Sesayap Kabupaten Tana Tidung.

Bawono, Icuk Rangga. 2003. "Manajemen Strategik Sektor Publik: Langkah Tepat Menuju Good Governance.” Jurnal Fakultas Ekonomi UNSOED Purwokerto.

Bernard, H. (2011). Research Methods in Anthropology. Alta Mira Press.

Braun, V., \& Clarke, V. (2006). "Using thematic analysis in psychology." Qualitative Research in Psychology, 3 (2), 77-101.

Penelitian Lestari (2014) "Membedah Akuntabilitas Pengelolaan Keuangan Desa Pakraman Kubutambahan, Kecamatan Kubutambahan, Kabupaten Buleleng, Provinsi Bali (Sebuah Studi Interpretif pada Organisasi Publik Non Pemerintahan)”

Istiqomah. (2015). "Efektifitas Kinerja Badan Permusyawaratan Desa dalam Meningkatkan Akuntabilitas Pengelolaan Keuangan Desa (Studi pada Pengelolaan Alokasi Dana Desa di Desa Ringintunggal Kec. Gayam Kab. Bojonegoro Tahun 2013)”

Hanifah dan Praptoyo. (2015). "Akuntabilitas dan Transparansi Pertanggungjawaban Anggaran Pendapatan Belanja Desa (APBDes)" 
Jurnal Kompetitif : Media Informasi Ekonomi Pembangunan, Manajemen dan Akuntansi

Vol. 6 No. 2 September 2020

Setiawan dkk. (2017). "Akuntabilitas Pengelolaan Dana Desa di Desa Budugsidorejo Kabupaten Jombang Tahun 2015”

Giofani inge Aria H .(2019). “Akuntabilitas pengelolaan Dana Desa (Studi Kasus di Desa Air Mandidi Kecamatan Teluk Kimi Kabupaten Nabire Provinsi Papua).

BPKP. 2015. Petunjuk Pelaksanaan Bimbingan \& Konsultasi Pengelolaan Keuangan Desa.

David, M., \& Sutton, C. (2011). Social research: an introduction. (Thousand Oaks, Ed.). CA: SAGE Publications, Inc.

Howitt, D., \& Cramer, D. (2008). Introduction to research methods in psychology. (Harlow, Ed.) (2nd edn). Essex: Pearson Education Limited.

Jauhari, Arief, Hasan Basri, and M. Shabri. 2015. "Penerapan Good Governance Berbasis EGovernment Dan Reformasi Birokrasi Dalam Rangka Meningkatkan Kinerja Satuan Kerja Pemerintah Aceh.” Jurnal Administrasi Akuntansi: Program Pascasarjana Unsyiah 4(3): 57-70.

Jensen, Michael C, and W. Meckling. 1976. "Theory of The Firm: Managerial Behavior, Agency Costs and Ownership Structure." Journal of Financial Economics 3: 305-60.

Jones, S., \& Forshaw, M. (2012). Research methods in psychology. (Harlow, Ed.).

Essex: Pearson Prentice Hall.

Kemendagri. 2014. "Perkembangan Paradigma Good Governance." Kemendagri. http://www.kemendagri.go.id/article/2014/06/12/perkembangan-paradigma- $\quad$ goodgovernance (April 25, 2018).

Kompas. 2015. "Jokowi Terbitkan PPP, Pagu Anggaran Dana Desa Bisa Berubah.”Kompas.com.https://nasional.kompas.com/read/2015/05/18/02344391/Jokowi.Ter bitkan.PP.Pagu.Anggaran.Dana.Desa.Bisa.Beruah (April 26, 2020).

Laksmi, A. C. (2015). Continuing Professional Development For The Auditing Profession: Evidence From Indonesia. RMIT University. 
Jurnal Kompetitif : Media Informasi Ekonomi Pembangunan, Manajemen dan Akuntansi Vol. 6 No. 2 September 2020

Mardiasmo. 2004. Akuntansi Sektor Publik. Yogyakarta: Andi Offset.

McCracken, G. (1988). The Long Interview. Newbury Park: Sage Publications Inc.

Mondong, Hendra. 2013. "Peran Pemerintah Desa Dalam Meningkatkan Partisipasi Masyarakat Dalam Pembangunan Desa.” ejournal unstrat 5(1): 1-18. 